\title{
Bibliography
}

\section{List of interviews}

I Paul Astbury (by telephone, I9 February 2019)

2 Dame Margaret Beckett MP (House of Commons, London, 24 October 2018)

3 Tony Blair (Tony Blair Institute for Change, London, I7 April 2019)

4 Lord David Blunkett (Sheffield, I2 October 2018)

5 Charles Clarke (Cambridge, i8 May 2018)

6 Jon Cruddas MP (House of Commons, London, 28 November 2018)

7 Lord Murray Elder (House of Lords, London, 23 January 2019)

8 Baroness Joyce Gould (Brighton, 29 November 2018)

9 Baroness Dianne Hayter (by telephone, 29January 2019)

Io Anji Hunter (London, I3 March 20i9)

I I Baroness Maggie Jones (House of Lords, London, 28 November 2018)

I2 Jane Kennedy PCG (Liverpool, 8 November 2018)

I3 Peter Kilfoyle (Liverpool, I4 December 2018)

I4 Lord Neil Kinnock (House of Lords, London, 27 March 2018)

I5 Ian Lowes (by telephone, i8 February 20I9)

I6 Lord Peter Mandelson (London, I8 March 2019)

I7 Baroness Margaret McDonagh (London, I February 2019)

I8 Baroness Sally Morgan (by telephone, 30 July 20i8)

I9 Tony Mulhearn (Liverpool, I4 December 2018)

20 Lord John Prescott (University of Hull, 28 July 2018)

2I Lord Tom Sawyer (London, 6 November 2015)

22 Dennis Skinner MP (by telephone, 2 I May 2018)

23 Harry Smith (by telephone, i8 February 20i9)

24 Lord Larry Whitty (House of Lords, London, 28 November 2018) 


\section{Bibliography}

\section{Archives}

Papers of Rodney Bickerstaffe (Modern Record Centre, Warwick University) Campaign for Labour Party Democracy Archive (Bishopsgate Institute, London)

Papers of Dianne Hayter (Labour History Archive and Study Centre, People's History Museum, Manchester)

Lord Roy Hattersley Archive (Hull History Centre)

Labour Party Archives (Labour History Archive and Study Centre, People's History Museum, Manchester)

Labour Solidarity Campaign (Hull History Centre)

Militant Tendency Archive (Modern Record Centre, Warwick University)

Lord Neil Kinnock Archive (Churchill College, Cambridge University)

Lord John Prescott Archive (Hull History Centre)

Chris Mullin Archive (Hull History Centre)

NUPE and UNISON Archive (Modern Record Centre, Warwick University) Lord Tom Sawyer Archive (Teesside University)

\section{Private papers}

The Journal of Lord Tom Sawyer

Personal Papers of Lord Tom Sawyer

\section{Labour Party publications}

Labour Party. Agenda for Change. London: Labour Party, 1992.

Labour Party. Aims and Values: The Consultation Report. London: Labour Party, I995.

Labour Party. Britain Will Win. London: Labour Party, I987.

Labour Party. Democracy and Policy Making for the I9gos. London: Labour Party, I990.

Labour Party. Democracy Review. London: Labour Party, 2018.

Labour Party. Democratic Socialist Aims and Values. London: Labour Party, I988.

Labour Party. It's Time to get Britain Working Again. London: Labour Party, I992.

Labour Party. Labour into Power: A Framework for Partnership. London: Labour Party, i996.

Labour Party. Labour Party/Trade Union links: Interim Report of the Review Group and Questionnaire. London: Labour Party, I993. 


\section{Bibliography}

Labour Party. Labour's Objects: Socialist Values in the Modern World. London: Labour Party, I994.

Labour Party. Looking to the Future. London: Labour Party, I990.

Labour Party. Meet the Challenge, Make the Change: A New Agenda for Britain. Final

Report of Labour's Policy Review for the I99os. London: Labour Party, I989.

Labour Party. NEC Report 1973. London: Labour Party, I973.

Labour Party. NEC Report 1974. London: Labour Party, I974.

Labour Party. Opportunity Britain. London: Labour Party, I99I.

Labour Party. Partnership in Power (June 1997 Consultation Document).

London: Labour Party, I997.

Labour Party. Partnership in Power. London: Labour Party, I997.

Labour Party. Partnership in Power: Rule Changes Proposed by the NEC. London:

Labour Party, 1997 .

Labour Party. Report of the Annual Conference of the Labour Party 1973-1998.

London: Labour Party, 1973-98.

Labour Party. Rule Book 1993-94. London: Labour Party, I994.

Labour Party. Rule Book 20I7. London: Labour Party, 2017.

Labour Party. Rule Book 2018. London: Labour Party, 2018.

Labour Party. Social Fustice and Economic Efficiency. London: Labour Party, I988.

Labour Party. The New Hope for Britain: Labour's Manifesto I983. London: Labour Party, I983.

Labour Party. Trade Unions and the Labour Party: Final Report of the Review Group on Links between the Trade Unions and the Labour Party. London: Labour Party, I993.

\section{Online archives}

Black, Ann [https://www.annblack.co.uk/reports_of_meetings].

Hansard [https://api.parliament.uk/historic-hansard/index.html].

Pack, Mark PollBase [https://www.markpack.org.uk/opinion-polls].

\section{Newspaper archives}

Guardian

Mirror

New Socialist

The Times

Tribune 


\section{Bibliography}

\section{Books and articles}

Alderman, Keith, and Carter, Neil. 'The Labour Party and the Trade Unions: Loosening the Ties'. Parliamentary Affairs, 47:3 (I994): 32I-7.

Allaun, Frank, Mikardo, Ian, and Sillars, Jim. Labour: Party or Puppet? London: Tribune Group, I972.

Anderson, Paul, and Mann, Nyta. Safety First: The Making of New Labour. London: Granta Books, I997.

Anderson, Perry. English Questions. London: Verso, I992.

Audickas, Lukas, Hawkins, Oliver, and Cracknell, Richard. UK Election Statistics 19I8-20I7. House of Commons Briefing Paper CBP7529. London: House of Commons, 2017.

Avril, Emmanuelle. 'The Evolution of Decision-Making in the British Labour Party: From Grassroots to Netroots?' In New Technology, Organizational Change and Governance, eds Emmanuelle Avril and Christine Zumello, I02-I7. London: Palgrave Macmillan, 2013.

Baker, Kenneth. The Turbulent Years: My Life in Politics. London: Faber \& Faber, 2003.

Bale, Tim. "'The Death of the Past": Symbolic Politics and the Changing of Clause IV'. In British Elections and Parties Yearbook 1996, eds David Farrell, David Broughton, David Denver and Justin Fisher, I58-77. London: Frank Cass, i996.

Beckett, Francis. Gordon Brown: Past, Present and Future. London: Haus Books, 2007.

Beckett, Francis, and Hencke, David. The Survivor: Tony Blair in Peace and War. London: Aurum Press, 2005.

Beech, Matt. The Political Philosophy of New Labour. London: I. B. Tauris, 2006.

Benn, Tony. Conflicts of Interest: Diaries 1977-80. London: Random House, I990.

Benn, Tony. End of an Era: Diaries 1980-9o. London: Random House, 1992.

Benn, Tony. Free at Last: Diaries 199I-200I. London: Arrow Books, 2003.

Bevir, Mark. 'The Remaking of Labour, I987-I997'. Observatoire de la Société Britannique, 7 (2009): 35 $\mathrm{I}-66$.

Blair, Tony. A fourney. London: Hutchinson, 2010.

Blair, Tony. Let us Face the Future: The 1945 Anniversary Lecture. London: Fabian Society, I995.

Blair, Tony. New Britain: My Vision of a Young Country. London: Fourth Estate, I996.

Blunkett, David. The Blunkett Tapes: My Life in the Bear Pit. London: Bloomsbury, 2006.

Blunkett, David. On a Clear Day. London: Michael O’Mara, 2002. 


\section{Bibliography}

Blunkett, David, and Crick, Bernard. The Labour Party's Aims and Values: An Unofficial Statement. Nottingham: Spokesman, I988.

Boothroyd, Betty. The Autobiography. London: Century, 200 I.

Brivati, Brian, and Heffernan, Richard. The Labour Party: A Centenary History. London: Palgrave Macmillan, 2000.

Bower, Tom. Broken Vows: Tony Blair, The Tragedy of Power. London: Faber \& Faber, 2016.

Bower, Tom. Gordon Brown: Prime Minister. London: Harper Perennial, 2007.

Brown, Colin. Prescott: The Biography. London: Politico's, 2005.

Brown, Gordon. My Life, Our Times. London: Bodley Head, 2017.

Butler, David, and Kavanagh, Dennis. The British General Election of 1992. London: Macmillan, I992.

Callaghan, John. The Far Left in British Politics. London: Blackwell, I987.

Campbell, Alastair. Diaries: Volume One, Prelude to Power. London: Hutchinson, 2010.

Campbell, Anne, Macdonald, Callum, Raynsford, Nick, Wicks, Malcolm, and Wright, Tony. A New Agenda. London: Institute for Public Policy Research, I993.

Crewe, Ivor. SDP: The Birth, Life and Death of the Social Democratic Party. Oxford: Oxford University Press, I995.

Crewe, Ivor. 'The Policy Agenda: A New Thatcherite Consensus?' Contemporary Record, 3:3 (1990): 2-7.

Crick, Michael. The March of Militant. London: Faber \& Faber, I986.

Crick, Michael. Militant. London: Biteback, 2016.

Cronin, James. New Labour's Pasts. London: Routledge, 2004.

Cruddas, Jon, and Harris, John. Fit for Purpose: A Programme for Labour Party Renewal. London: Compass, 2007.

Davies, Liz. Through the Looking Glass: A Dissenter inside New Labour. London: Verso, 200I.

Driver, Stephen, and Martell, Luke. 'From Old Labour to New Labour: A Comment on Rubinstein'. Politics, 21: (2001): 47-50.

Driver, Stephen, and Martell, Luke. New Labour: Politics after Thatcherism. Cambridge: Polity Press, I999.

Drower, George. Kinnock: A Biography. London: The Publishing Corporation, I994.

Elliott, Gregory. Labourism and the English Genius: The Strange Death of Labour England? London: Verso, I993.

Fabian Society. A New Constitution for the Labour Party: The Report of the Archer Committee. London: Fabian Society, I993.

Fielding, Steven. Labour: Decline and Renewal. London: Baseline, I999.

Fielding, Steven. The Labour Party: Continuity and Change in the Making of New Labour. London: Palgrave Macmillan, 2002. 


\section{Bibliography}

Frost, Diane, and North, Peter. Militant Liverpool: A City on the Edge. Liverpool: Liverpool University Press, 2013.

Fryer, Bob, and Williams, Stephen. Leadership and Democracy: The History of the National Union of Public Employees: Volume 2 1928-1993. London: Lawrence \& Wishart, 20II.

Garner, Robert, and Kelly, Richard. British Political Parties Today. Manchester: Manchester University Press, I998.

Golding, John. Hammer of the Left: Defeating Tony Benn, Eric Heffer and Militant in the Battle for the Labour Party. London: Biteback Publishing, 2016.

Gould, Bryan. Goodbye to All That. London: Macmillan, I995.

Gould, Joyce. Witchfinder General. London: Biteback Publishing, 2016.

Gould, Philip. The Unfinished Revolution: How New Labour Changed British Politics For Ever. London: Little, Brown and Company, 201 I.

Haddon, Catherine. Making Policy in Opposition: The Commission on Social fustice. London: Institute for Government, 2012.

Harris, Robert. The Making of Neil Kinnock. London: Faber \& Faber, I984.

Hattersley, Roy. Choose Freedom: The Future for Democratic Socialism. London: Michael Joseph, I987.

Hattersley, Roy. Who Goes Home: Scenes from a Political Life. London: Abacus, I995.

Hatton, Derek. Inside Left. London: Bloomsbury, I988.

Hay, Colin. 'Labour's Thatcherite Revisionism: Playing the "Politics of Catch-Up"'. Political Studies, 42:4 (I994): 700-7.

Hay, Colin. The Political Economy of New Labour: Labouring Under False Pretences. Manchester: Manchester University Press, I999.

Hayter, Dianne. Fightback! Labour's Traditional Right in the I97os and Ig8os. Manchester: Manchester University Press, 2005.

Hayter, Dianne. 'St Ermins Group'. In Dictionary of National Biography [https:// doi.org/Io.Iog3/ref:odnb/9669o].

Hayter, Dianne. 'The Fightback of the Traditional Right in the Labour Party I979 to I987'. PhD thesis, Queen Mary, University of London, 2004.

Heffer, Eric. Labour's Future: Socialist or SDP Mark 2? London: Verso, i983.

Healey, Denis. The Time of My Life. London: Penguin, I99o.

Heath, Anthony, Jowell, Rodger, and Curtice, John, The Rise of New Labour. Oxford: Oxford University Press, $200 \mathrm{I}$.

Heffernan, Richard. 'Labour's Transformation: A Stage Process with No Single Point of Origin'. Politics, I8:2 (1998): Io -6.

Heffernan, Richard. New Labour and Thatcherism. Hampshire: Macmillan, 2000.

Heffernan, Richard, and Marqusee, Mike. Defeat from the Fawes of Victory: Inside Kinnock's Labour Party. London: Verso Books, 1992.

Heppell, Timothy. Choosing the Labour Leader: Labour Party Leadership Elections from Wilson to Brown. London: I. B. Tauris, 2010. 


\section{Bibliography}

Hill, Richard. The Labour Party and Economic Strategy, I997-1997: The Long Road Back. Hampshire: Palgrave, 200I.

House of Commons Information Office. By-Election Results 1987-02: Factsheet MI2. London: House of Commons Information Office, 2003.

Hughes, Colin, and Wintour, Patrick. Labour Rebuilt: The New Model Party. London: Fourth Estate, I99o.

Jenkins, Roy. A Life at the Centre. London: Pan Books, I99I.

Jones, Eileen. Neil Kinnock. London: Robert Hale, I994.

Jones, Mervyn. Michael Foot. London: Victor Gollancz, I994.

Jones, Tudor. 'Labour's Constitution and Public Ownership: From Old Clause Four to New Clause Four'. In The Labour Party: A Centenary History, eds Brian Brivati and Richard Heffernan, 292-32r. London: Macmillan, 2000.

Jones, Tudor. Remaking the Labour Party: From Gaitskell to Blair. London: Routledge, 1996.

Jowell, Roger, Hedges, Barry, Lynn, Peter, Farrant, Graham, and Heath, Anthony. 'Review: The 1992 British Election: The Failure of the Polls'. The Public Opinion Quarterly, 57:2 (1993): 238-63.

Kampfner, John. Robin Cook: The Life and Times of Tony Blair's Most Awkward Minister. London: Phoenix, I998.

Kavanagh, Dennis, and Butler, David. The British General Election of 1992. London: Palgrave Macmillan, I992.

Keohane, Dan. Labour Party Defence Policy since 1945. Leicester: Leicester University Press, I993.

Kilfoyle, Peter. Left Behind: Lessons from Labour's Heartland. London: Politico's, 2000.

Kinnock, Neil. 'Reforming the Labour Party'. Contemporary Record, 8:3 (I994): $535^{-54}$.

Kogan, David. Protest and Power: The Battle for the Labour Party. London: Bloomsbury, 2019.

Kogan, David, and Kogan, Maurice. The Battle for the Labour Party. London: Kogan Page, I982.

Labour Co-ordinating Committee. The Forward March of Modernisation. London. Labour Co-ordinating Committee, I998.

Labour Reform. Reforming Labour: Reclaiming the People's Party. London: Polemic Books, 200I.

Langdon, Julia. Mo Mowlam: The Biography. London: Little, Brown and Company, 2000.

Leapman, Michael. Kinnock. London: Unwin Hyman, I987.

Lees-Marshment, Jennifer. Political Marketing and British Political Parties. Manchester: Manchester University Press, 2008.

Lent, Adam. 'Labour's Transformation: Searching for the Point of Origin'. Politics, I7:I (1997): 9-15. 


\section{Bibliography}

Levy, Michael. 'Modernisation and Clause IV Reform: The Attitudes of Labour Backbench MPs'. In British Elections and Parties Yearbook 1996, eds David Farrell, David Broughton, David Denver and Justin Fisher, I78-97. London: Frank Cass, I996.

Livingstone, Ken. You Can't Say That: Memoirs. London: Faber \& Faber, 20 I .

Ludlam, Steve. 'The Making of New Labour'. In New Labour in Government, ed.

Steve Ludlam and Martin Smith, I-3I. London: Macmillan, 200 I.

Macintyre, Donald. Mandelson and the Making of New Labour. London: HarperCollins, 2000.

Mandelson, Peter. The Blair Revolution Revisited. London: Politico's, 2002.

Mandelson, Peter. The Third Man: Life at the Heart of New Labour. London: Harper Press, 2010.

Marqusee, Mike. 'New Labour and its Discontents'. New Left Review, 224 (I997): $127-42$.

Marsh, David. The New Politics of British Trade Unionism: Union Power and the Thatcher Legacy. Hampshire: Macmillan, I992.

Massey, Christopher. 'The Militant Tendency and Entrism in the Labour Party'. In Waiting for the Revolution: The British Far Left since 1956, ed. Matt Worley and Evan Smith, 238-257. Manchester: Manchester University Press, 2017.

Matthias, Glyn, and Cowling, David. 'The ITN Exit Poll'. In Political Communications: The General Election Campaign of 1992, eds Ivor Crewe and Brian Gosschalk, 242-6. Cambridge: Cambridge University Press, I995.

McSmith, Andy. Faces of Labour: The Inside Story. London: Verso Books, I997.

McSmith, Andy. Fohn Smith: A Life 1938-1994. London: Mandarin, I993.

Mikardo, Ian. Back-Bencher. London: Weidenfeld \& Nicolson, I988.

Minkin, Lewis. The Blair Supremacy: A Study in the Politics of Labour's Party Management. Manchester: Manchester University Press, 2015.

Minkin, Lewis. The Contentious Alliance: Trade Unions and the Labour Party. Edinburgh University Press: Edinburgh, I99I.

Mitchell, Austin. Four Years in the Death of the Labour Party. London: Methuen, I983.

Morgan, Kenneth. Michael Foot: A Life. London: Harper Perennial, 2008.

Morgan, Kenneth. 'The Historical Roots of New Labour'. History Today, 48:10 (1998): 15-28.

Mortimer, Jim. A Life on the Left. Sussex: The Book Guild, I998.

Mullin, Chris. A Walk on Part: Diaries 1994-1999. London: Profile, 2012.

Naughtie, James. The Rivals: Blair and Brown: The Intimate Story of a Political Marriage. London: Fourth Estate, 200I.

Osler, David. The Labour Party PLC: The Truth Behind New Labour as a Party of Business. Edinburgh: Mainstream, 2002.

Owen, David. Time to Declare. London: Penguin, 1992. 


\section{Bibliography}

Panitch, Leo, and Leys, Colin. The End of Parliamentary Socialism: From New Left to New Labour. London: Verso, $200 \mathrm{I}$.

Parkinson, Michael. Liverpool on the Brink: One City's Struggle against Government Cuts. Berkshire: Policy Journals, I985.

Pattie, Charles. 'New Labour and the Electorate'. In New Labour in Government, eds Steve Ludlam and Martin Smith, 32-54. London: Macmillan, 200 I.

Powell, Jonathan. The New Machiavelli. London: Vintage, 20 I I.

Prescott, John. Docks to Downing Street: Fohn Prescott, My Story. London: Headline Review, 2009.

Pugh, Martin. Speak for Britain: A New History of the Labour Party. London: Vintage, 20II.

Pye, Neil. 'Militant's Laboratory: Liverpool City Council's struggle with the Thatcher Government'. In Labour and the Left in the I980s, eds Jonathan David and Rohan McWilliam, I5 ${ }^{\mathrm{I}}$-7I. Manchester: Manchester University Press, 2017.

Quinn, Thomas. Modernising the Labour Party: Organisational Change since 1983. Hampshire: Palgrave Macmillan, 2005.

Radice, Giles. Diaries 1980-200I: From Political Disaster to Election Triumph. London: Weidenfeld \& Nicolson, 2004.

Radice, Giles. Southern Discomfort. London: Fabian Society, I992.

Rentoul, John. Tony Blair. London: Little, Brown and Company, 200 I.

Rentoul, John. 'Tony Blair'. In Leading Labour: From Keir Hardie to Tony Blair, ed. Kevin Jeffreys, 208-29. London: I. B. Tauris, I999.

Riddell, Peter. 'The end of Clause IV'. Contemporary British History, i I:2 (I997): 24-49.

Riddell, Peter. The Unfulfilled Prime Minister: Tony Blair's Quest for a Legacy. London: Politico's, 2005.

Rodgers, Bill. Fourth Among Equals. London: Pan Books, I991.

Rosen, Greg. Old Labour to New. The Dreams that Inspired, the Battles that Divided. London: Politico's, 2005.

Rosen, Greg. 'Tom Sawyer (Lord Sawyer of Darlington)'. In Dictionary of Labour Biography, Greg Rosen, 500-2. London: Politico's, $200 \mathrm{I}$.

Routledge, Paul. Gordon Brown: The Biography. London: Pocket Books, I998.

Routledge, Paul. Mandy. London: Pocket Books, I999.

Russell, Meg. Building New Labour: The Politics of Party Organisation. London: Palgrave, 2005.

Rye, Daniel. 'Political Parties and Power: A Multi-dimensional Analysis'. $\mathrm{PhD}$ thesis, University of London, 2012.

Sassoon, Donald. One Hundred Years of Socialism. London: I. B. Tauris, 2014.

Seldon, Anthony. Blair. London: Simon \& Schuster, 2005.

Seyd, Patrick. 'Labour Government-Party Relationships: Maturity or Marginalisation?' In Britain at the Polls 200I, ed. Anthony King, 95-II6.

New York: Chatham House, 2002. 


\section{Bibliography}

Seyd, Patrick. 'Labour: The Great Transformation'. In Britain at the Polls 1992, ed. Anthony King, 70-10o. London: Chatham House, 1992.

Seyd, Patrick. 'New Parties/New Politics? A Case Study of the British Labour Party'. Party Politics, 5:3 (I999): 383-405.

Seyd, Patrick. 'The Labour Left'. PhD thesis, University of Sheffield, I987.

Seyd, Patrick. The Rise and Fall of the Labour Left. London: Palgrave, I987.

Seyd, Patrick. 'Tony Blair and New Labour'. In New Labour Triumphs, Britain at the Polls 1997, ed. Anthony King, 49-74. New Jersey: Chatham House, I998.

Seyd, Patrick, and Whiteley, Paul. Labour's Grass Roots: The Politics of Party Membership. Oxford: Oxford University Press, I996.

Seyd, Patrick, and Whiteley, Paul. 'New Labour and the Party: Members and Organisation'. In New Labour in Government, eds Steve Ludlam and Martin Smith, 73-9i. London: Macmillan, 200I.

Shaw, Eric. Discipline and Discord in the Labour Party. Manchester: Manchester University Press, I988.

Shaw, Eric. The Labour Party Since 1945. London: Blackwell, I996.

Shaw, Eric. The Labour Party Since 1979: Crisis and Transformation. London: Routledge, I994.

Shaw, Eric. 'The Control Freaks? New Labour and the Party'. In Governing as New Labour: Policy and Politics Under Blair, eds Steve Ludlam and Martin Smith, 52-69. London: Palgrave Macmillan, 2004.

Shaw, Eric. 'Towards Renewal? The British Labour Party's Policy Review'. West European Politics, i6:I (1993): I12-32.

Shipley, Peter. The Militant Tendency: Trotskyism in the Labour Party. London: Foreign Affairs Publishing, I983.

Short, Clare. An Honourable Deception?' New Labour, Iraq and the Misuse of Power. London: Simon \& Schuster, 2004.

Smith, John. Guiding Light: The Collected Speeches of John Smith. London: Politico's, 2000.

Smith, Martin. 'Continuity and Change in Labour Party Policy'. In The Changing Labour Party, ed. Martin Smith and Hannah Spears, 217-29. London: Routledge, I992.

Smith, Martin. "Understanding the "Politics of Catch-Up": The Modernization of the Labour Party'. Political Studies, 42:4 (I994): 708-I5.

Sopel, Jon. The Moderniser. London: Bantam, I995.

Stark, Leonard. Choosing a Leader: Party Leadership Contests in Britain from Macmillan to Blair. Hampshire: Macmillan, I996.

Stevens, Philip. Tony Blair. London: Politico's, 2004.

Straw, Jack. Last Man Standing: Memoirs of a Political Survivor. London: Pan, 2013.

Straw, Jack. Policy and Ideology. Blackburn: Blackburn Labour Party, I993.

Stuart, Mark. Fohn Smith: A Life. London: Politico's, 2005.

Taaffe, Peter. The Rise of Militant. London: Militant Publications, I995. 


\section{Bibliography}

Taaffe, Peter, and Mulhearn, Tony. Liverpool: A City that Dared to Fight. London: Fortress, I988.

Taylor, Andrew. Trade Unions and the Labour Party. London: Croom Helm, I987.

Taylor, Gerald. Labour's Renewal? The Policy Review and Beyond. London: Palgrave, I997.

Wainwright, Hilary. Labour: A Tale of Two Parties. London: Hogarth Press, 1987.

Waller, Robert. 'The Polls and the 1992 General Election'. In Political Communications: The General Election Campaign of 1992, eds Ivor Crewe and Brian Gosschalk, I77-9I. Cambridge: Cambridge University Press, I995.

Westlake, Martin. Kinnock. London: Little, Brown and Company, 2001.

Whiteley, Paul. The Labour Party in Crisis. London: Methuen, I983.

Wickham-Jones, Mark. Economic Strategy and the Labour Party; Politics and PolicyMaking, 1970-83. London: Macmillan, I996.

Wickham-Jones, Mark. 'Introducing OMOV: The Labour Party-Trade Union Review Group and the 1994 Leadership Contest'. British Fournal of Industrial Relations, 52: (2014): 33-56.

Wickham-Jones, Mark. 'John Smith's Settlement? The Work of the 1992-93 Labour Party-Trade Union Links Review Group'. Industrial Relations foumal, 47:I (2016): 2I-45.

Wickham-Jones, Mark. 'Recasting Social Democracy'. Political Studies, 43:4 (I995): 698-702.

Williams, Shirley. Climbing the Bookshelves: The Autobiography. London: Virago, 2009.

Wring, Dominic. The Politics of Marketing the Labour Party. London: Palgrave Macmillan, 2005.

Young, Alison. The Reselection of MPs. London: Heinemann Educational Books, ig83.

Young, Ross. 'The Labour Party and the Labour Left'. PhD thesis, University of Oxford, 200I. 